\title{
Olive Stone Ash as Secondary Raw Material for Fired Clay Bricks
}

\author{
D. Eliche-Quesada, ${ }^{1}$ M. A. Felipe-Sesé, ${ }^{1,2}$ and A. Infantes-Molina ${ }^{3}$ \\ ${ }^{1}$ Department of Chemical, Environmental, and Materials Engineering, Advanced Polytechnic School of Jaén, University of Jaén, \\ Campus Las Lagunillas s/n, 23071 Jaén, Spain \\ ${ }^{2}$ International University of La Rioja, Avenida La Paz, No. 137, Logroño, 26002 La Rioja, Spain \\ ${ }^{3}$ Department of Inorganic Chemistry, Crystallography and Mineralogy, Affiliate Unit of the ICP-CSIC, Faculty of Sciences, \\ University of Málaga, Campus de Teatinos, 29071 Málaga, Spain \\ Correspondence should be addressed to D. Eliche-Quesada; deliche@ujaen.es
}

Received 5 September 2016; Revised 9 November 2016; Accepted 27 November 2016

Academic Editor: Kaveh Edalati

Copyright (C) 2016 D. Eliche-Quesada et al. This is an open access article distributed under the Creative Commons Attribution License, which permits unrestricted use, distribution, and reproduction in any medium, provided the original work is properly cited.

This work evaluates the effect of incorporation of olive stone ash, as secondary raw material, on the properties of fired clay bricks. To this end, three compositions containing 10, 20, and $30 \mathrm{wt} \%$ olive stone ash in a mixture of clays (30 wt $\% \mathrm{red}, 30 \mathrm{wt} \%$ yellow, and $40 \mathrm{wt} \%$ black clay) from Spain were prepared. The raw materials, clay and olive stone ash, were characterized by means of XRD, XRF, SEM-EDS, and TG-TDA analysis. The engineering properties of the press molded specimens fired at $900^{\circ} \mathrm{C}(4 \mathrm{~h})$ such as linear shrinkage, bulk density, apparent porosity, water absorption, and compressive strength were evaluated. The results indicated that the incorporation of $10 \mathrm{wt} \%$ of olive stone ash produced bricks with suitable technological properties, with values of compressive strength of $41.9 \mathrm{MPa}$ but with a reduced bulk density, by almost $4 \%$. By contrast, the incorporation of $20 \mathrm{wt} \%$ and $30 \mathrm{wt} \%$ sharply increased the water absorption as a consequence of the large amount of open porosity and low mechanical strength presented by these formulations, which do not meet the standards for their use as face bricks. The bricks do not present environmental problems according to the leaching test.

\section{Introduction}

Among renewable energy sources, biomass plays a very important role in the new energy framework, since agricultural residues are produced in relatively large quantities all over the world. Spain, deficient in fossil energy resources, is very rich in biomass resources. According to the Food and Agriculture Organization of the United Nations (FAO), Spain is the main world producer of olives, with 4,577,000 tons in 2014, followed by Greece, Italy, Turkey, and Morocco [1]. In 2015, the production of olives in Spain increased, representing 7,344,820 tons with a cultivated surface area of $2,526,496$ ha [2]. In particular, the olive sector in Andalusia, region of southern Spain, has grown over the years due to expansion and intensification of olive groves, which cover 1.5 million hectares of olives groves and depict $60 \%$ of the total cultivation area of the country in 2012 [3]. Therefore, the oil sector can be considered as the greater producer of biomass in Andalusia [4]. The main biomass employed for thermal use in the Andalusian industrial sector is the products derived of its olive industry, as olive stone, pomace, and leaves [5].

The cultivation of the olive grove is dedicated to two uses: production of olive oil and table olives production. The most important waste generated in both industries is the olive stone. In Andalusia, about 360,000 t/year of crushed stone is generated: 0.083 tons of stones is generated per ton of olive (11.5\%). Also in the table olive industry around 22,000 tons of whole stone [4] is generated. Between the different ways of exploitation of olive stone, its use as an adsorbent, after its transformation into active carbon; in the treatment of waste water of chemical and pharmaceutical industries [6-9]; as electrodes for Li-ion batteries [10,11]; and for furfural production, plastic filled, abrasive and cosmetics, animal feed, or resin formation is found [12].

Recently, its use in the production of building bricks has been studied $[13,14]$. Nonetheless, the main use is as fuel to produce electric energy or heat. This source of renewable energy, biomass, which has tremendous potential to mitigate 
the global warming, likewise contributes to the increase of the value of the residues and reduction of the environmental impact of the waste disposal. The stone is a fuel presenting excellent features: high density, average humidity of $15 \%$, very uniform particle size, and a calorific power of $4,500 \mathrm{kcal} / \mathrm{kg}$ in a dry base. It is very suitable for thermal applications, both own mills and other industries, greenhouse, domestic and residential use, and municipal facilities as swimming pools, schools, and parks, due to the low emissions of particles in its combustion and odorless conditions.

The combustion of olive stone has been associated with the production of residues of combustion, such as ashes. Currently, the greater part of the combustion ashes of olive stone are either arranged in a landfill or recycled in agricultural fields. Although ashes are considered as nonhazardous industrial waste according to the Ministry of Environment and so specified in the European list of waste 10.01.01 and 10.01.03 codes [15], the ashes generated in the biomass combustion process carry an economic and environmental load.

On the other hand, the presence of volatile heavy metals in these ashes can also have negative environmental effects if managed and eliminated without care, due to the possible leaching in surface and underground water [16].

Nowadays, the ceramic and cement industry includes manufacturing processes that make the recovery of wastes possible, taking advantage of the calorific powder from their combustion or by incorporating them into the internal structure of materials, forming part of its own matrix and becoming an inert element especially viable $[17,18]$. In this regard, in the last years a great number of researches are devoted to the incorporation of different combustion ashes into ceramic bricks in order to valorize a waste and improve the properties of the resultant material according to the standards. Palm oil fuel ash [19], rice husk ash [20, 21], sugarcane bagasse ash and rice husk ash [22], municipal solid waste incineration fly ash $[23,24]$, sewage sludge incinerator ash [25, 26], olive pomace bottom ash [27], olive pomace fly ash $[28,29]$, and wood ash [30] have been studied. However, the use of olive stone combustion ash to manufacture ceramic materials has not been studied yet.

Therefore, the objective of this work is to evaluate the use of olive stone ashes as secondary raw material in the manufacturing of ceramic materials. The raw materials, clay and stone ash, were characterized in terms of chemical composition, crystalline phases, and thermal behavior. The influence of olive stone ash proportion was therefore examined. Clay brick samples containing $0-30 \mathrm{wt} \%$ of waste were mixed, molded, and sintered at $900^{\circ} \mathrm{C}$. Engineering properties such as bulk density, apparent porosity, water absorption, and compressive strength were studied as a function of ash content.

\section{Experimental Procedures}

2.1. Raw Materials. The olive stone ash was collected by Geolit Air Conditioning Enterprise, society promoted by Valoriza Energy, Inverjaen, Geolit, Agener, and Thermal Power Stations and Networks. This society located in the technological park of Geolit (located in Mengibar, Jaén, Spain) develops a centralized eco-efficient and innovative air conditioning system, with important benefits for the environment. The olive stone ash samples were collected from the mechanical hopper in the station. The collected sample was mixed and homogenized using suitable coning and quartering procedures. Finally, the samples were sieved to particle diameter less than $100 \mu \mathrm{m}$.

The clay was supplied by a clay pit located in Bailen, Jaén (Spain). It was obtained by mixing three types of raw clay in the following percentages: $30 \mathrm{wt} \%$ red, $30 \mathrm{wt} \%$ yellow, and $40 \mathrm{wt} \%$ black clay. To obtain uniform particle size, the clay was crushed and ground to yield a powder with a particle size suitable to pass through a $500 \mu \mathrm{m}$ sieve.

2.2. Characterization of Raw Materials. The surface of the olive stone ash and mixed clay was characterized using scanning electron microscopy and energy dispersive X-ray spectrometry SEM/EDX using the high-resolution transmission electron microscope JEOL SM 840. Samples were placed on an aluminium grate and coated with carbon using the ion sputtering device JEOL JFC 1100. Crystalline phases were analyzed by using X'Pert Pro MPD automated diffractometer (PANalytical) equipped with a Ge (111) primary monochromator, using monochromatic $\mathrm{Cu} \operatorname{K} \alpha$ radiation $(\lambda=1.5406 \AA)$ and X'Celerator detector. The chemical composition was determined by X-ray fluorescence (XRF) using the Philips Magix Pro (PW-2440). The thermal behavior was determined by thermogravimetric and differential thermal analysis (TGDTA) with a Mettler Toledo 851e device in oxygen. The total content of carbon, hydrogen, nitrogen, and sulphur was determined by combustion of samples in $\mathrm{O}_{2}$ atmosphere using the CHNS-O Thermo Finnigan Elementary Analyzer Flash EA 1112.

\subsection{Preparation and Testing of Fired Olive Stone Ash-Clay} Bricks. Three olive stone ash-clay mixtures were prepared by adding the proper amount of ashes in order to obtain mixtures containing 10,20, and $30 \mathrm{wt} \%$ of ash. Samples were homogenized in a mortar. To enable comparative results, ten samples per series were prepared for testing. The necessary amount of water ( $8 \mathrm{wt} \%$ moisture) was added to the samples to obtain adequate plasticity and absence of defects, mainly cracks, during the semidry compression molding stage under $54.5 \mathrm{MPa}$ of pressure, using uniaxial laboratory-type pressing Mega KCK-30 A. Waste-free mixtures were also made as references. Solid bricks with $30 \times 10 \mathrm{~mm}$ cross sections and a length of $60 \mathrm{~mm}$ were obtained. Samples were fired in a laboratory furnace at a rate of $3^{\circ} \mathrm{C} / \mathrm{min}$ up to $900^{\circ} \mathrm{C}$ for $4 \mathrm{~h}$. Samples were then cooled to room temperature by natural convection inside the furnace. The shaped samples were designated as $\mathrm{C}$ for the bricks without olive stone ash and C- $x$ OSA for the mixtures, where $x$ denotes the ash content (\%) in the clay matrix. Figure 1 depicts the scheme of the preparation process followed.

Linear shrinkage was obtained by measuring the length of samples before and after the firing stage by using a caliper with a precision of $\pm 0.01 \mathrm{~mm}$, according to ASTM standard C326 [31]. Water absorption values were determined from weight difference between the as-fired and water-saturated samples (immersed in boiling water for $2 \mathrm{~h}$ ), according to 
TABLE 1: Carbonate content, organic content, and CNHS analysis of raw materials.

\begin{tabular}{lcccccc}
\hline Sample & Carbonate content $^{(\mathrm{a})}(\%)$ & Organic matter content $(\%)$ & $\% \mathrm{C}$ & $\% \mathrm{H}$ & $\% \mathrm{~N}$ & $\% \mathrm{~S}$ \\
\hline OSA & $39.54 \pm 0.89$ & $11.83 \pm 0.12$ & $11.60 \pm 0.01$ & $0.40 \pm 0.02$ & $0.012 \pm 0.0$ & 0.0 \\
Clay & $7.36 \pm 0.33$ & $2.29 \pm 0.09$ & $2.25 \pm 0.01$ & $0.34 \pm 0.004$ & $0.05 \pm 0.002$ & $0.032 \pm 0.008$ \\
\hline
\end{tabular}

(a) Determined according to ASTM D-2974.

TABLE 2: Chemical composition of OSA and clay.

\begin{tabular}{|c|c|c|c|c|c|c|c|c|c|c|c|c|c|c|c|}
\hline Oxide content (\%) & $\mathrm{SiO}_{2}$ & $\mathrm{Al}_{2} \mathrm{O}_{3}$ & $\mathrm{Fe}_{2} \mathrm{O}_{3}$ & $\mathrm{CaO}$ & $\mathrm{MgO}$ & $\mathrm{MnO}$ & $\mathrm{K}_{2} \mathrm{O}$ & $\mathrm{TiO}_{2}$ & $\mathrm{P}_{2} \mathrm{O}_{5}$ & $\mathrm{SO}_{3}$ & $\mathrm{ZnO}$ & $\mathrm{SrO}$ & $\mathrm{ZrO}_{2}$ & $\mathrm{Cl}$ & LOI \\
\hline OSA & 8.47 & 1.68 & 2.97 & 24.0 & 3.42 & 0.057 & 31.22 & 0.073 & 4.04 & - & 0.03 & 0148 & - & 0.074 & 23.8 \\
\hline Clay & 54.4 & 12.4 & 4.58 & 8.76 & 2.46 & 0.03 & 3.37 & 0.60 & 0.11 & 0.68 & 0.03 & 0.027 & 0.033 & - & 12.5 \\
\hline
\end{tabular}

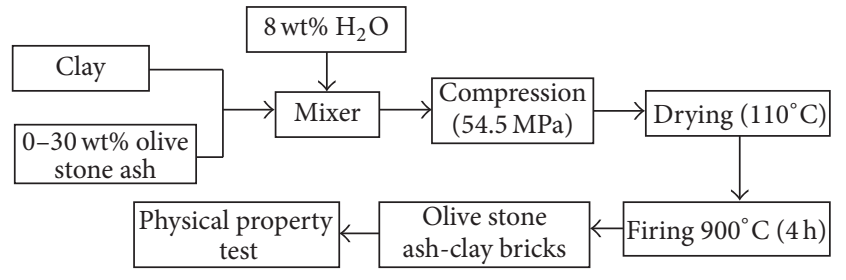

FIGURE 1: Flowchart of producing clay-olive stone ash bricks.

the ASTM standard C373 [32]. Bulk density was determined by the Archimedes method [32]. Water suction of a brick is defined as the volume of water absorbed during short partial immersion. Tests to determine water suction were implemented according to the standard procedure UNE-EN 772-1 [33].

Compressive strength of bricks is their bulk unit charge against breakage under axial compressive strength. For this trial, six fired samples were studied. Tests on compressive strength were performed according to the standard UNE-EN 772-1 [34] on MTS 810 Material Testing Systems laboratory press. The area of both bearing surfaces was measured and the average taken. All samples were submitted to a progressively increasing normal strength, with the load applied centered on the upper surface of the sample until breakage. The compressive strength of each sample was obtained by dividing the maximum load by the average surface of both bearing surfaces, expressed in MPa with $0.1 \mathrm{MPa}$ accuracy.

Finally, leachability of heavy metals in the samples was studied using the toxicity characteristic leaching procedure (TCLP) according to EPA method 1311 (Environmental Protection Agency, Method 13-11, 1992) [35]. The concentrations in the filtrate were measured with an Inductively Coupled Plasma-Atomic Emission Spectrometer (ICP-AES Agilent 7500).

\section{Results and Discussion}

3.1. Raw Materials Characterization. The olive stone ash received had about 1.0\% moisture content. In Figure 2, the SEM image of dried ash is shown. The particle morphology showed the presence of irregular, angled particles of $40-$ 70 microns, some spherical particles, and clusters formed by sintering agglomeration during the thermal process. The chemical composition of the olive stone ash determined by EDS indicated the presence of significant percentages of K, $\mathrm{Ca}$, and $\mathrm{Si}$. The spherical particles had a higher proportion of Ca.

The weight loss was investigated by calcination of the sample, grain size $<100 \mu \mathrm{m}$, at $900^{\circ} \mathrm{C}$ for $3 \mathrm{~h}$. The weight loss observed was $21.9 \%$, indicating a high amount of unburned matter in the ash. This result indicated that the use of this material directly to form green bodies could lead to a significant volume reduction with the concomitant deformation or breakage of the bricks if the sintering process is not carried out at an adequate heating rate. The CNHS analysis of the olive ash (Table 1) showed that it was composed mainly of carbon (11.6\%) and small quantities of hydrogen $(0.40 \%)$ and nitrogen $(0.012 \%)$. It did not contain sulphur. These data indicated that the olive stone ash contained large amounts of organic carbon pointing to incomplete combustion of the olive stone and therefore an inefficient fuel use $[36,37]$.

The particle size distribution of the olive stone ash showed an average particle size $D_{50}$ of $59.4 \mu \mathrm{m}$. The ash presented a percentage of fine particles $(<0.002 \mathrm{~mm})$ of $1.31 \mathrm{vol} \%$, a lime content $(0.002-0.063 \mathrm{~mm})$ of $47.1 \mathrm{vol} \%$, and a sand content $(0.063-2 \mathrm{~mm})$ of $51.6 \mathrm{vol} \%$. Therefore, the broad particle size caused a lack of homogeneity in the mixed, and so a further process to homogenize the grain size to a particle size of $100 \mu \mathrm{m}$ was necessary.

The chemical composition of the raw materials, olive stone and clay, used in this study is shown in Table 2. If the ash is considered, it was mainly composed ( $>55 \mathrm{wt} \%)$ of $\mathrm{K}_{2} \mathrm{O}(31.2 \mathrm{wt} \%)$ and $\mathrm{CaO}(24.0 \%)$. Oxides such as $\mathrm{SiO}_{2}, \mathrm{P}_{2} \mathrm{O}_{5}$, $\mathrm{MgO}, \mathrm{Fe}_{2} \mathrm{O}_{3}$, and $\mathrm{Al}_{2} \mathrm{O}_{3}$, in decreasing order of abundance, were present in a $1-10 \mathrm{wt} \%$ proportion, whereas $\mathrm{SrO}$ was a minor oxide $(0.1-1 \mathrm{wt} \%)$. The chloride content was low, $0.07 \mathrm{wt} \%$. High contents of fluxing oxides $\left(\mathrm{K}_{2} \mathrm{O}\right)$ and auxiliary fluxing oxides $\left(\mathrm{CaO}, \mathrm{MgO}\right.$, and $\left.\mathrm{Fe}_{2} \mathrm{O}_{3}\right)$ are desired to lower the firing process temperature for brick preparation. The total content of $\mathrm{Si}$ and $\mathrm{Al}$ (estimated as oxides) was lower than the values obtained in other bottom ashes due to their low level in the feeding fuel.

On the other hand, the clay was mainly composed of silica, aluminium, and calcium oxides (54.4 wt\%, $12.4 \mathrm{wt} \%$, and $8.8 \mathrm{wt} \%$, resp.). The clay mixture also contained a small amount of fluxing agents, $\mathrm{K}_{2} \mathrm{O}$ and $\mathrm{MgO}$, accompanied by a higher amount of iron oxide (4.6 wt\%). Clay and mainly olive stone ash presented high LOI values (12.5\% for clay and $23.8 \%$ 

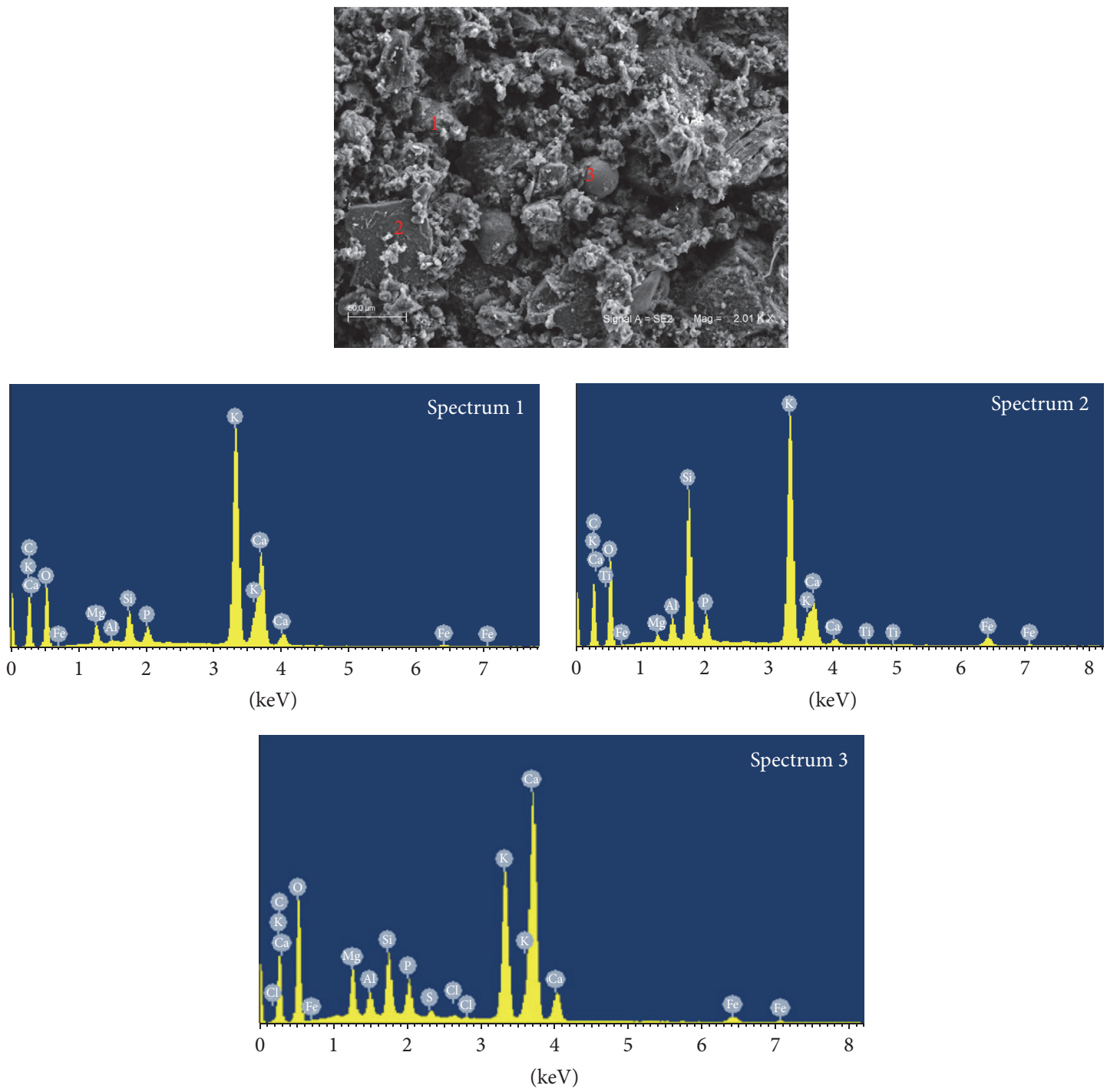

FIGURE 2: SEM/EDX of olive stone as used as raw material for clay bricks.

for OSA) which were associated with the organic matter (2.3\% for clay and $11.8 \%$ for OSA) and carbonate contents (7.4\% for clay and $39.5 \%$ for OSA) (Table 1). During firing, organic matter and carbonates act as pore-forming agents and carbonates also generate crystalline phases, which enhance mechanical strength [38].

The crystalline phases present in the raw materials were evaluated by means of XRD. Figure 3 lumped together both diffractograms. In the diffractogram corresponding to pure clay (Figure 3(a)), several contributions can be observed. The main diffraction peaks were related to the presence of quartz, calcite, and dolomite. Some tiny diffraction peaks also revealed the presence of feldspar and a small amount of gypsum and phyllosilicates. On the other hand, the diffractogram corresponding to olive stone ash was complex and a great number of diffraction peaks were noticeable. The phases present were mainly associated with carbonates of $\mathrm{K}$ and $\mathrm{Ca}$. Thus the main phase was a carbonate of $\mathrm{K}$ and $\mathrm{Ca}$ hydrated, $\mathrm{K}_{2} \mathrm{CO}_{3} \cdot(3 / 2) \mathrm{H}_{2} \mathrm{O}$ (PDF $\mathrm{P}^{\circ}$ : 98-002-2257). As it will be seen below, this sample loses $5 \mathrm{wt} \%$ of weight associated with moisture. The second phase observed was anhydrous carbonate of $\mathrm{Ca}$ and $\mathrm{K}, \mathrm{K}_{2} \mathrm{Ca}\left(\mathrm{CO}_{3}\right)_{2}$ (PDF N ${ }^{\circ}$ 01-083-1921 and PDF $\mathrm{N}^{\circ}$ 98-000-6177). Other tiny diffraction peaks matched with several silicates although the contribution of these peaks was low. XRD results agree with XRFS ones that indicated that $\mathrm{Ca}$ and $\mathrm{K}$ were the main elements present as well as a great amount of $\mathrm{C}$ derived from $\mathrm{CNH}$ analysis.

The thermal characterization of the raw materials is provided in Figure 4. The thermal decomposition profile of OSA showed a weight loss between 30 and $200^{\circ} \mathrm{C}$ with a weight loss of $5.6 \%$ associated with moisture. The organic matter and unburned elements, as residual carbon, decomposition occurred between 200 and $550^{\circ} \mathrm{C}$ [39] and a weight loss of $9.3 \%$ accompanied with a single strong exothermic peak centered at $425^{\circ} \mathrm{C}$ was present. Between 550 and $800^{\circ} \mathrm{C}$, a weight loss of $5.1 \%$ was observed and several thermal effects were clearly visible. At $650^{\circ} \mathrm{C}$, a slight endothermic peak associated with structural water release from hydroxide ions 
TABLE 3: Technological properties of fired construction bricks made from clay and olive stone ash.

\begin{tabular}{lcccc}
\hline Sample & Waste content $(\mathrm{wt} \%)$ & Linear shrinkage $(\%)$ & Loss on ignition $(\%)$ & Suction water $\left(\mathrm{kg} / \mathrm{m}^{2} \mathrm{~min}\right)$ \\
\hline C & 0 & $-0.518 \pm 0.10$ & $9.24 \pm 0.09$ & $2.32 \pm 0.07$ \\
C-10OSA & 10 & $-0.88 \pm 0.12$ & $12.97 \pm 0.08$ & $2.59 \pm 0.22$ \\
C-20OSA & 20 & $-1.88 \pm 0.14$ & $15.19 \pm 0.08$ & $3.06 \pm 0.06$ \\
C-30OSA & 30 & $-2.19 \pm 0.15$ & $17.19 \pm 0.09$ & $2.88 \pm 0.08$ \\
\hline
\end{tabular}

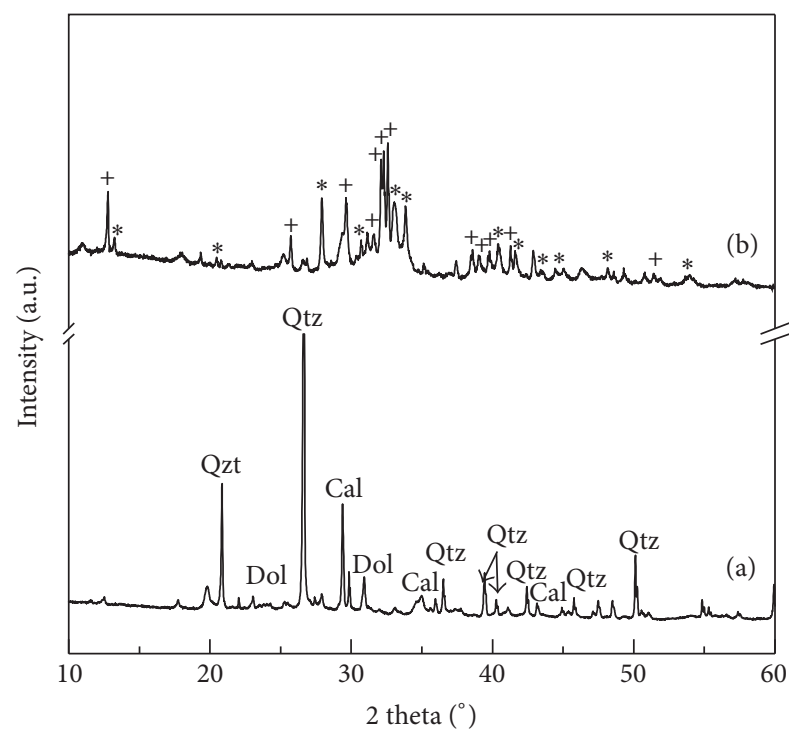

FIGURE 3: XRD patterns of (a) starting raw clay (Qtz: quartz, Cal: calcite, and Dol: dolomite $)$ and (b) olive stone ash $\left(+: \mathrm{K}_{2} \mathrm{CO}_{3} \cdot(3 / 2) \mathrm{H}_{2} \mathrm{O}\right.$; *: $\left.\mathrm{K}_{2} \mathrm{Ca}\left(\mathrm{CO}_{3}\right)_{2}\right)$.

present in the ash was observed. The exothermic peak at $700^{\circ} \mathrm{C}$ was probably due to the combustion of unburned elements present in the ashes, whereas the endothermic effect at $750^{\circ} \mathrm{C}$ may be assigned to the decomposition of the carbonates in the ashes, emitting $\mathrm{CO}_{2}$.

The TG-DTA analysis of the clay sample also showed several processes. Between 30 and $150^{\circ} \mathrm{C}$, the moisture was removed (1.0 wt\%). Between 100 and $650^{\circ} \mathrm{C}$, the weight loss observed (2.75 wt\%) was due to dehydroxylation reactions of clay minerals and organic matter decomposition. The main weight loss was obtained between 650 and $900^{\circ} \mathrm{C}$ (7.7 wt\%) and associated with calcium carbonate decomposition. The DTA curve showed that dehydration, dehydroxylation, and decarbonation reactions were endothermic processes, with peaks centered at $85^{\circ} \mathrm{C}, 570^{\circ} \mathrm{C}$, and $760^{\circ} \mathrm{C}$, respectively. The decomposition of organic matter is an exothermic process, with peaks centered at about $375^{\circ} \mathrm{C}$ and $475^{\circ} \mathrm{C}$.

\subsection{Technological Properties of Fired Olive Stone Ash-Clay} Bricks. In order to evaluate the application of clay bricks containing 10-30 wt\% of olive stone ash, their technological properties were evaluated. During the firing process, changes in mass, dimensions, and color of the fired clay bricks occur. In this case, it was observed that by increasing the amount of ash in the brick the red color of the bricks was lighter.
No defects as cracks, bloating, or efflorescence were observed after firing at $900^{\circ} \mathrm{C}$ (Figure 5).

The changes in linear shrinkage for bricks after firing are shown in Table 3. Control bricks showed linear shrinkage of $-0.5 \%$, exhibiting an expansion behavior. The addition of olive stone ash increased the linear shrinkage up to $-2.2 \%$ with the addition of $30 \mathrm{wt} \%$ of waste, which is a typical behavior of porous bricks, due to the relative high level content of organic matter and carbonates in the samples (Table 1). The OSA waste was formed by $8.5 \%$ of $\mathrm{SiO}_{2}$ and $1.7 \%$ of $\mathrm{Al}_{2} \mathrm{O}_{3}$, only a $10.2 \%$ of waste weight was made of skeleton components. Flux materials (58.6\%) and gaseous components (11.8\% $\mathrm{CaCO}_{3}$ and $39.5 \%$ organic matter) were found in higher proportions. When the temperature grew from room temperature to $900^{\circ} \mathrm{C}$, the addition of OSA produced liquid phase at lower temperature and a decrease in temperature at sintering onset due to the higher content in flux materials. Also calcite decomposed at $800^{\circ} \mathrm{C}$ and organic matter at $550^{\circ} \mathrm{C}$, generating $\mathrm{CO}_{2}$. However, at firing temperature of $900^{\circ} \mathrm{C}$, the liquid phase allowed gas trapping, an increase in gas pressure inside the closed pores, which tended to expand the pores [40]. As a result, bulk density decreased rapidly. Such behavior reflects that the effect of porosity formed in the material with high OSA content was greater than the effect provided by the melting capacity of the waste.

These values are considered to be within the safety limits for industrial production of fired clay bricks.

The loss of ignition (LOI) of the bricks after the firing process at $900^{\circ} \mathrm{C}$ was $9.24 \%$ for control bricks (Table 3). The control brick samples showed the lowest value and it is related to dehydroxylation reactions, loss of humidity, organic matter combustion, and carbonate decomposition. The olive stone ash is an inorganic-organic waste due to high amount of organic matter (Table 1). Therefore, by increasing OSA proportion, the loss on ignition of fired bricks increased from $12.97 \%$ up to $17.19 \%$ with additions of 10 and $30 \mathrm{wt} \%$ of waste, respectively.

Considering the bulk density, the addition of OSA decreased it (Figure 6), with values ranging from 1,767 to $1,553 \mathrm{~kg} / \mathrm{m}^{3}$, lower than the value for the control brick $\left(1,839 \mathrm{~kg} / \mathrm{m}^{3}\right)$. The addition of $10 \mathrm{wt} \%$ of ash resulted in a reduction of $3 \%$ achieving the maximum reduction after adding $30 \mathrm{wt} \%$ of OSA, $15.6 \%$. There was an almost linear decrease in bulk density as the ash content increased. The reduction in bulk density is due to the combustion of the organic content and carbonates decomposition contained in the residue causing porosity in the clay body.

Another parameter evaluated was the water suction, which affects the quality and durability of the final materials. 

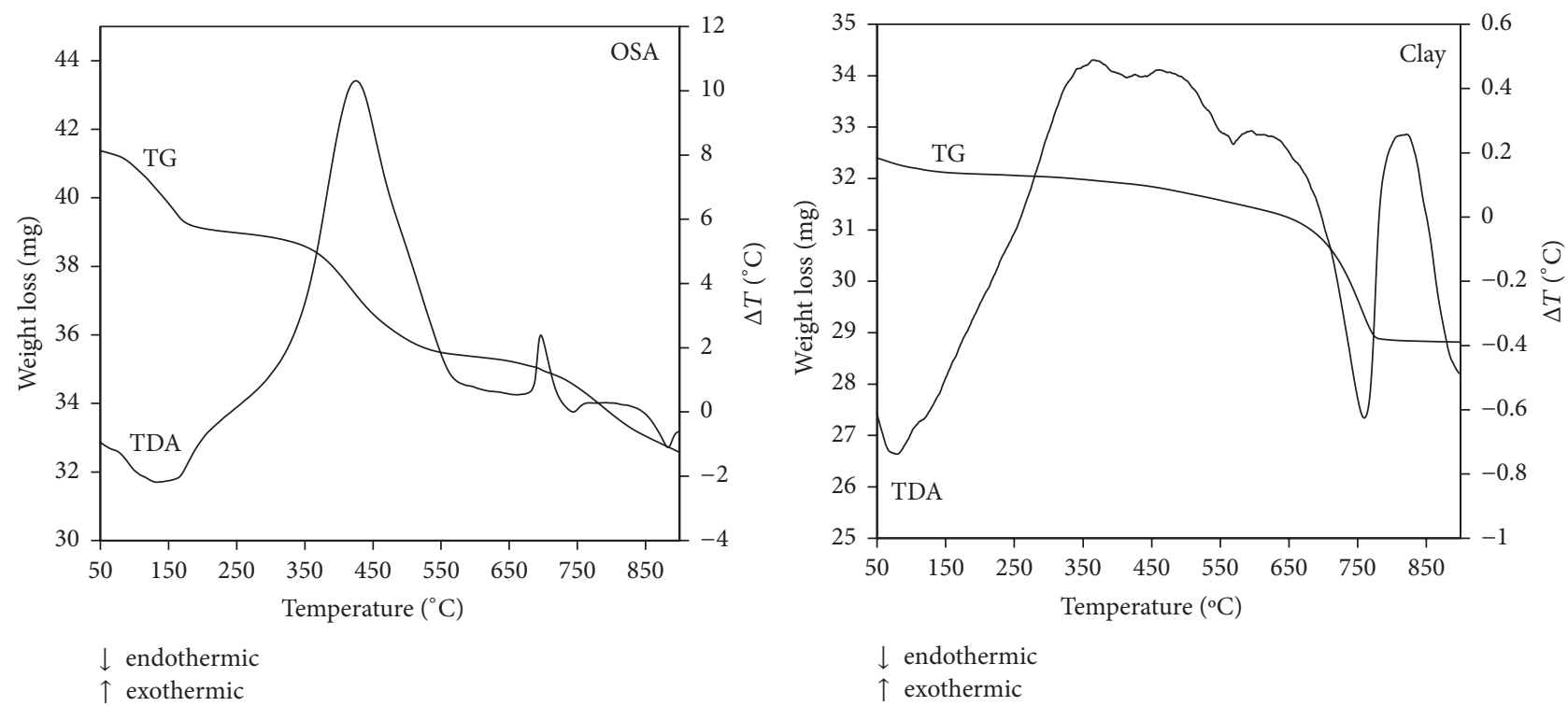

FIGURE 4: TG-DTA analysis of (a) olive stone ash and (b) raw clay.

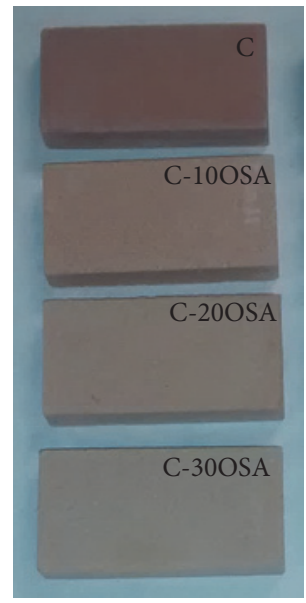

FIGURE 5: Bricks obtained by pressing of olive stone ash mixed with clay and fired at $900^{\circ} \mathrm{C}$.

This is a property of adherence among brick and mortar. The results of water suction as a function of OSA percentage added are included in Table 3. As seen from this table, the water suction of the clay showed a value of $2.32 \mathrm{~kg} / \mathrm{m}^{2} \min$ and varied with the percentage of olive stone ash added. The maximum suction value, $3.06 \mathrm{~kg} / \mathrm{m}^{2} \mathrm{~min}$, was achieved for the sample containing $20 \mathrm{wt} \%$ of ash. The water suction values were instead lower for C-10OSA and C-30OSA samples, $2.59 \mathrm{~kg} / \mathrm{m}^{2} \mathrm{~min}$ and $2.88 \mathrm{~kg} / \mathrm{m}^{2} \mathrm{~min}$, respectively. Therefore, the incorporation of olive stone ash produced an increase in the interconnected surface porosity possibly due to pore growth, both in size and in number, due to the organic and carbonates content. In accordance with standard UNE bricks [33] water suction must be less than $4.5 \mathrm{~kg} / \mathrm{m}^{2} \mathrm{~min}$ because the brick removes water from the mortar causing inadequate curing. However, if the water suction value is

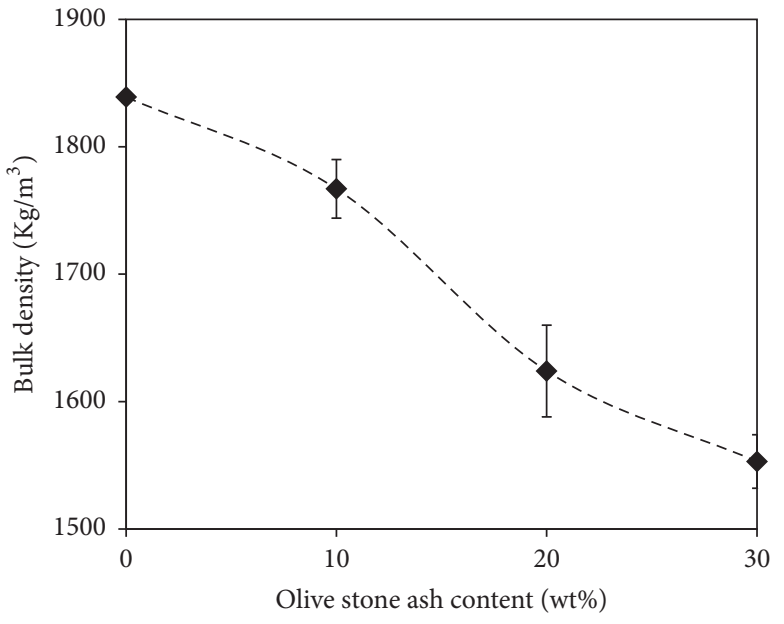

FIGURE 6: Bulk density of the fired bricks as function of olive stone ash addition.

higher than $0.15 \mathrm{~kg} / \mathrm{m}^{2} \mathrm{~min}$, brief immersion in water of the brick is needed before its placement to avoid the dehydration of the mortar. All the bricks agree with regulations.

If the apparent porosity is considered, the addition of OSA produced a significant increase in the apparent porosity of the resultant bricks, increasing from $31.0 \%$ for the standard clay brick up to $36.9 \%$ for C-30OSA brick (Figure 7). The addition of $10 \mathrm{wt} \%$ of OSA gave rise to bricks with an apparent porosity of $34.8 \%$ increasing this property about $12 \%$ with regard to the control sample. The addition of higher amounts of OSA, 20 and $30 \mathrm{wt} \%$, produced a higher increase (about $18 \%)$ in apparent porosity.

Water absorption is another key factor affecting the durability of brick and shows the same trend compared to apparent porosity. The water absorption is an indirect indicator of open porosity. The results of the water absorption 


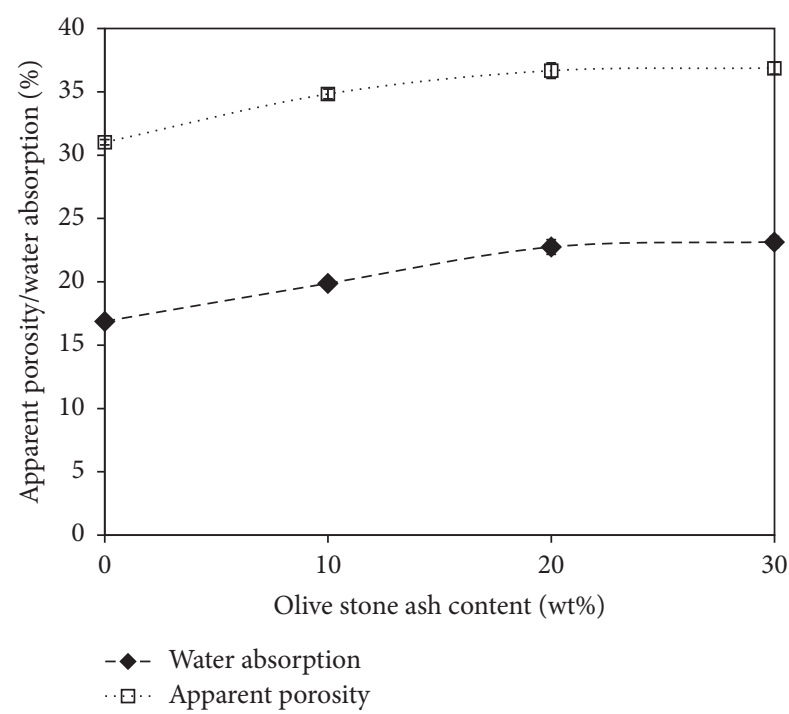

FIGURE 7: Apparent porosity and water absorption of the fired bricks as function of olive stone ash addition.

tests (Figure 7) showed that the absorption capacity rose with OSA incorporation into the clay matrix. The water absorption of the control bricks presented the minimum value $16.9 \%$. Instead, the values for C-10OSA, C-20OSA, and C-30OSA were $19.9 \%, 22.8 \%$, and $23.1 \%$, respectively, due to an increase of the open porosity as a consequence of organic matter and carbonates decomposed during the firing process. In any case, the maximum water absorption value is limited by standards ASTMC67-14 [41]. Depending on both, the main purpose of the brick and the environment, values must be below $17 \%$ for bricks exposed to severe weathering conditions and $22 \%$ for bricks exposed to moderate weathering conditions and no limit is set for negligible weathering resistance bricks. The addition of $20 \mathrm{wt} \%$ and $30 \mathrm{wt} \%$ of OSA resulted in bricks with very high water absorption values that do not fall within the standards of conventional bricks.

Compressive strength is the most critical index for building materials. According to ASTM C62-10 [42] and European Standard EN-772-1 [34], the compressive strength varies from $10 \mathrm{MPa}$ for weather-resistant brick to $20 \mathrm{MPa}$ in the case of severe weathering. Compressive strength of fired products is shown in Figure 8. Compressive strength rapidly decreased at higher ratio of olive stone ash in bricks, especially when the ratio is equal to or higher than $20 \mathrm{wt} \%$. The highest value obtained corresponds to control bricks (53.3 $\mathrm{MPa})$. The compressive strength values decreased a $21.6 \%$, down to $41.9 \mathrm{MPa}$, for $\mathrm{C}-10 \mathrm{OSA}$ sample. In the case of C-20OSA and C-30OSA, the compressive strength was reduced up to $33.2 \mathrm{MPa}$ and $31.1 \mathrm{MPa}$, respectively. These results are in accordance with data for bulk density, apparent porosity, and water absorption. Bulk density of bricks was reduced as the amount of olive stone ash increased, to reach $1,553 \mathrm{~kg} / \mathrm{m}^{3}$ compared to $1,839 \mathrm{~kg} / \mathrm{m}^{3}$ for control bricks. At high OSA additions (20 or $30 \mathrm{wt} \%$ ), waste bricks of higher porosity and higher water absorption were produced. Open pores with irregular shape and microscopic imperfections may concentrate pressure and decrease the mechanical properties

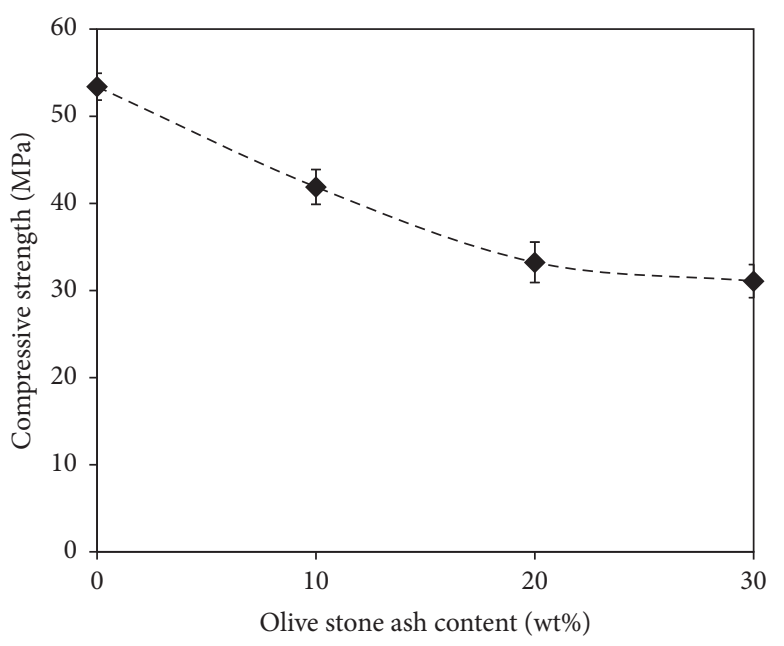

FIGURE 8: Compressive strength of the fired bricks as a function of olive stone ash addition.

of fired bricks [43]. In the present study, strength values of all samples containing ash were higher than $20 \mathrm{MPa}$.

In order to valorize the use of olive stone ash in obtaining fired clay bricks, the leachability of heavy metals was evaluated. Table 4 presents heavy metal concentrations measured in the extract obtained after the leaching test of the ceramic bricks with different quantities of olive stone ash by TCLP test EPA 1311 method [35]. The results show that only $\mathrm{Cr}$ was detected in small concentration, always lower than the control brick. This indicates that the amount of chrome was higher in the clay than in the olive stone ash. Concentrations of As, Cd, Co, Cr, Ni, Sn, and V increased as the proportion of olive stone ash did. However, it was observed that the use of olive stone ash gave rise to concentrations of heavy metals much lower than the limits established by EPA 658/2009 [35]. From these results, ceramic bricks fabricated with $10-30$ wt $\%$ of olive stone ash can be classified as inert and nondangerous for the environment. Leaching tests showed a high degree of immobilization of heavy metals, highlighting that the incorporation of the different amounts (10-30 wt\%) of olive stone ash in fired clay bricks production is an efficient method of immobilization. Hence, no environmental problems due to heavy metals disposal can be expected by the use of the OSAclay fired bricks.

\section{Conclusions}

The valorization of olive stone ash (OSA) in the manufacturing of fired clay bricks is a sustainable way to reduce the harmful environmental impacts of these wastes. The OSA is a waste predominantly composed of potassium, calcium, and silicon but also contains organic matter. The addition of $10-30 \mathrm{wt} \%$ of OSA to a clay had a pronounced effect on the evolution of physical and mechanical properties of the resultant bricks fired at $900^{\circ} \mathrm{C}$. Increasing additions of waste decreased the compressive strength and bulk density of bricks and increased simultaneously their apparent porosity and water absorption. The compressive strength decreased 
TABLE 4: USEPA TCLP test results (ppm) and the maximum concentration of contaminants for toxicity characteristics of fired clay and fired clay-OSA bricks.

\begin{tabular}{|c|c|c|c|c|c|}
\hline Component (ppm) & $\mathrm{C}$ & C-10OSA & C-20OSA & C-30OSA & USEPA regulated TCLP limits (ppm) \\
\hline As & 0.027 & 0.061 & 0.028 & 0.015 & 5 \\
\hline $\mathrm{Ba}$ & 0.204 & 0.225 & 0.558 & 0.188 & 100 \\
\hline $\mathrm{Cd}$ & 0.0003 & 0.00020 & 0.00012 & 0.00008 & 1 \\
\hline Co & 0.010 & 0.0084 & 0.0013 & 0.0010 & - \\
\hline $\mathrm{Cr}$ & 0.554 & 0.297 & 0.282 & 0.234 & 5 \\
\hline $\mathrm{Cu}$ & 0.296 & 0.467 & 0.986 & 0.330 & 5 \\
\hline $\mathrm{Ni}$ & 0.047 & 0.070 & 0.012 & 0.0004 & - \\
\hline $\mathrm{Pb}$ & 0.0009 & 0.00043 & 0.087 & 0.00019 & 5 \\
\hline $\mathrm{Sb}$ & 0.0010 & 0.0036 & 0.0098 & 0.0057 & - \\
\hline Se & 0.013 & 0.018 & 0.0031 & 0.0032 & 1 \\
\hline Sn & 0.00014 & 0.00018 & 0.00016 & 0.00012 & - \\
\hline $\mathrm{V}$ & 0.161 & 0.351 & 0.200 & 0.115 & - \\
\hline $\mathrm{Hg}$ & 0.00004 & 0.00009 & 0.00011 & 0.00009 & 0.2 \\
\hline $\mathrm{Zn}$ & 0.058 & 0.012 & 0.005 & 0.006 & 300 \\
\hline
\end{tabular}

from 53.4 MPa in control bricks without OSA to $31.1 \mathrm{MPa}$ in bricks containing up to $30 \mathrm{wt} \%$ of waste. The decrease in the mechanical properties of OSA-fired clay bricks was due to a marked increase in open porosity as indicated by the water absorption data. The bulk density was between 4 and 16\% lower than the bulk density of control bricks.

The clay brick containing $10 \mathrm{wt} \%$ of olive stone ash showed an appropriate balance among the physical and mechanical properties such as bulk density $\left(1,767 \mathrm{~kg} / \mathrm{cm}^{3}\right)$, apparent porosity (34.8\%), water absorption (19.8\%), and compressive strength $(41.9 \mathrm{MPa})$. In order to decrease open porosity and to raise the amount of OSA waste in fired clay bricks further studies are required and should be focused on the sintering temperature.

The environmental behavior (TCLP test EPA 1311 method) of bricks showed that the leaching of all heavy metals was under the requested limits.

\section{Competing Interests}

The authors declare that they have no competing interests.

\section{Acknowledgments}

This work has been funded by the Project "Valuation of Various Types of Ash for the Obtaining of New Sustainable Ceramic Materials" (UJA2014/06/13), Own Plan University of Jaén, sponsored by Caja Rural of Jaén. Technical and human support provided by CICT of Universidad de Jaén (UJA, MINECO, Junta de Andalucía, FEDER) is gratefully acknowledged. A. Infantes-Molina thanks the Ministry of Economy and Competitiveness for a Ramón y Cajal contract (RyC2015-17870).

\section{References}

[1] Food and Agriculture Organization of the United Nations. Statistics Division, 2016, http://faostat3.fao.org/browse/Q/QC/ E.
[2] Ministerio de Agricultura, Alimentación y Medio Ambiente. Gobierno de España. Estadísticas, 2016, http://www.magrama .gob.es/es/estadistica/temas/estadisticas-agrarias/agricultura/ superficies-producciones-anuales-cultivos/.

[3] Ministerio de Agricultura, Alimentación y Medio Ambiente, Gobierno de España, Encuesta sobre Superficies y Rendimientos, 2013.

[4] Agencia Andaluza de la Energía (AAE), La biomasa en Andalucía, 2015, https://www.agenciaandaluzadelaenergia.es/ sites/default/files/3_2_0161_15_la_biomasa_en_andalucia_octubre_2015.pdf.

[5] Junta de Andalucía Biomasa Forestal en Andalucía, 1. Modelos de existencias, crecimiento y producción, Coníferas, 2012, http:// www.juntadeandalucia.es/medioambiente/portal_web/web/ temas_ambientales/montes/usos_y_aprov/jornadas_biomasa/ Publicaciones/biomasal.pdf.

[6] M. C. Trujillo, M. A. Martín-Lara, A. B. Albadarin, C. Mangwandi, and M. Calero, "Simultaneous biosorption of methylene blue and trivalent chromium onto olive stone," Desalination and Water Treatment, vol. 57, no. 37, pp. 17400-17410, 2015.

[7] S. Larous and A. Meniai, "Adsorption of Diclofenac from aqueous solution using activated carbon prepared from olive stones," International Journal of Hydrogen Energy, vol. 41, no. 24, pp. 10380-10390, 2016.

[8] A. Erto, B. Tsyntsarski, M. Balsamo et al., "Synthesis of activated carbons by thermal treatments of agricultural wastes for $\mathrm{CO}_{2}$ capture from flue gas," Combustion Science and Technology, vol. 188, no. 4-5, pp. 581-593, 2016.

[9] M. Balsamo, B. Tsyntsarski, A. Erto et al., "Dynamic studies on carbon dioxide capture using lignocellulosic based activated carbons," Adsorption, vol. 21, no. 8, pp. 633-643, 2015.

[10] N. Moreno, Á. Caballero, J. Morales, and E. RodríguezCastellón, "Improved performance of electrodes based on carbonized olive stones/S composites by impregnating with mesoporous $\mathrm{TiO}_{2}$ for advanced $\mathrm{Li}-\mathrm{S}$ batteries," Journal of Power Sources, vol. 313, pp. 21-29, 2016.

[11] N. Moreno, A. Caballero, L. Hernán, and J. Morales, "Lithiumsulfur batteries with activated carbons derived from olive stones," Carbon, vol. 70, pp. 241-248, 2014. 
[12] G. Rodríguez, A. Lama, R. Rodríguez, A. Jiménez, R. Guillén, and J. Fernández-Bolaños, "Olive stone an attractive source of bioactive and valuable compounds," Bioresource Technology, vol. 99, no. 13, pp. 5261-5269, 2008.

[13] S. Arezki, N. Chelouah, and A. Tahakourt, "The effect of the addition of ground olive stones on the physical and mechanical properties of clay bricks," Materiales de Construcción, vol. 66, no. 322, article no. e082, 2016.

[14] S. Serrano, C. Barreneche, and L. F. Cabeza, "Use of byproducts as additives in adobe bricks: mechanical properties characterisation," Construction and Building Materials, vol. 108, pp. 105-111, 2016.

[15] Decisión de la Comisión 2000/532/CE sobre lista de residuos, DO L n²26, 6.9.2000 modificada por Decisiones 2001/118/ CE, 2001/119/CE y 2001/573/CE y rectificada por DO L nº112, 27.4.2002, http://eur-lex.europa.eu/LexUriServ/LexUriServ.do? uri=CELEX:32000D0532:ES:HTML.

[16] D. Vamvuka, "Comparative fixed/fluidized bed experiments for the thermal behaviour and environmental impact of olive kernel ash," Renewable Energy, vol. 34, no. 1, pp. 158-164, 2009.

[17] A. Ravaglioli, C. Fiori, and B. Fabbri, Materie Prime Ceramiche. Argille, Materiali non Argillosi e Sottoprodotti Industriali, Faenza Editrice S.P.A. Faenza, 1989.

[18] L. Sánchez-Muñoz and J. B. Carda Castelló, "Materiales residuales," in De Materias Primas y Aditivos Cerámicos, F. E. Iberica and S. L. Castellón, Eds., pp. 159-160, 2002.

[19] A. A. Kadir, N. A. Mohd Zahari, and N. Azizi Mardi, "Utilization of palm oil waste into fired clay brick," Advances in Environmental Biology, vol. 7, no. 12, pp. 3826-3834, 2013.

[20] C.-L. Hwang and T.-P. Huynh, "Investigation into the use of unground rice husk ash to produce eco-friendly construction bricks," Construction and Building Materials, vol. 93, pp. 335341, 2015.

[21] S. Janbuala and T. Wasanapiarnpong, "Effect of rice husk and rice husk ash on properties of lightweight clay bricks," Key Engineering Materials, vol. 659, pp. 74-79, 2015.

[22] S. M. Kazmi, S. Abbas, M. A. Saleem, M. J. Munir, and A. Khitab, "Manufacturing of sustainable clay bricks: utilization of waste sugarcane bagasse and rice husk ashes," Construction and Building Materials, vol. 120, pp. 29-41, 2016.

[23] Z. Haiying, Z. Youcai, and Q. Jingyu, "Utilization of municipal solid waste incineration (MSWI) fly ash in ceramic brick: product characterization and environmental toxicity," Waste Management, vol. 31, no. 2, pp. 331-341, 2011.

[24] K. L. Lin, "Feasibility study of using brick made from municipal solid waste incinerator fly ash slag," Journal of Hazardous Materials, vol. 137, no. 3, pp. 1810-1816, 2006.

[25] M. Smol, J. Kulczycka, A. Henclik, K. Gorazda, and Z. Wzorek, "The possible use of sewage sludge ash (SSA) in the construction industry as a way towards a circular economy," Journal of Cleaner Production, vol. 95, pp. 45-54, 2015.

[26] P. Pavšič, A. Mladenovič, A. Mauko et al., "Sewage sludge/ biomass ash based products for sustainable construction," Journal of Cleaner Production, vol. 67, pp. 117-124, 2014.

[27] D. Eliche-Quesada and J. Leite-Costa, "Use of bottom ash from olive pomace combustion in the production of eco-friendly fired clay bricks," Waste Management, vol. 48, pp. 323-333, 2016.

[28] C. Fernández-Pereira, J. A. De La Casa, A. Gómez-Barea, F. Arroyo, C. Leiva, and Y. Luna, "Application of biomass gasification fly ash for brick manufacturing," Fuel, vol. 90, no. 1, pp. 220-232, 2011.
[29] J. A. de la Casa and E. Castro, "Recycling of washed olive pomace ash for fired clay brick manufacturing," Construction and Building Materials, vol. 61, pp. 320-326, 2014.

[30] L. Pérez-Villarejo, D. Eliche-Quesada, F. J. Iglesias-Godino, C. Martínez-García, and F. A. Corpas-Iglesias, "Recycling of ash from biomass incinerator in clay matrix to produce ceramic bricks," Journal of Environmental Management, vol. 95, supplement, pp. S349-S354, 2012.

[31] "Test method for drying and firing shrinkage of ceramic whiteware clays," ASTM C 326, American Society for Testing and Materials, 1997.

[32] "Test method for water absorption, bulk density, apparent porosity, and apparent specific gravity of fired whiteware products," ASTM C373, American Society for Testing and Materials, 1994.

[33] "Methods of test for masonry units-part 11: determination of water absorption of aggregate concrete, manufactured stone and natural stone masonry units due to capillary action and the initial rate of water absorption of clay masonry units," UNE-EN 772-11, 2011.

[34] "Methods of test for masonry units-part 1: determination of compressive strength," UNE EN 772-1, 2011.

[35] U.S. Environmental Protection Agency, Method 13-11 Toxicity Characteristics Leaching Procedure (TCLP), vol. 51, Federal Register, Washington, DC, USA, 1992.

[36] A. Demirbas, "Potential applications of renewable energy sources, biomass combustion problems in boiler power systems and combustion related environmental issues," Progress in Energy and Combustion Science, vol. 31, no. 2, pp. 171-192, 2005.

[37] O. Dahl, H. Nurmesniemi, R. Pöykiö, and G. Watkins, "Comparison of the characteristics of bottom ash and fly ash from a medium-size (32 MW) municipal district heating plant incinerating forest residues and peat in a fluidized-bed boiler," Fuel Processing Technology, vol. 90, no. 7-8, pp. 871-878, 2009.

[38] J. García-Ten, M. J. Orts, A. Saburit, and G. Silva, “Thermal conductivity of traditional ceramics: part II: Influence of mineralogical composition," Ceramics International, vol. 36, no. 7, pp. 2017-2024, 2010.

[39] I. J. Fernandes, D. Calheiro, A. G. Kieling et al., "Characterization of rice husk ash produced using different biomass combustion techniques for energy," Fuel, vol. 165, pp. 351-359, 2016.

[40] H. He, Q. Yue, Y. Su et al., "Preparation and mechanism of the sintered bricks produced from Yellow River silt and red mud," Journal of Hazardous Materials, vol. 203-204, pp. 53-61, 2012.

[41] "Standard test methods for sampling and testing brick and structural clay tile," ASTM C67-14, 2014.

[42] "Standard specification for building brick (solid masonry units made from clay or shale)," ASTM C62-10, ASTM International, West Conshohocken, Pa, USA, 2010.

[43] W. M. Carty and U. Senapati, "Porcelain-raw materials, processing, phase evolution, and mechanical behavior," Journal of the American Ceramic Society, vol. 81, no. 1, pp. 3-20, 1998. 

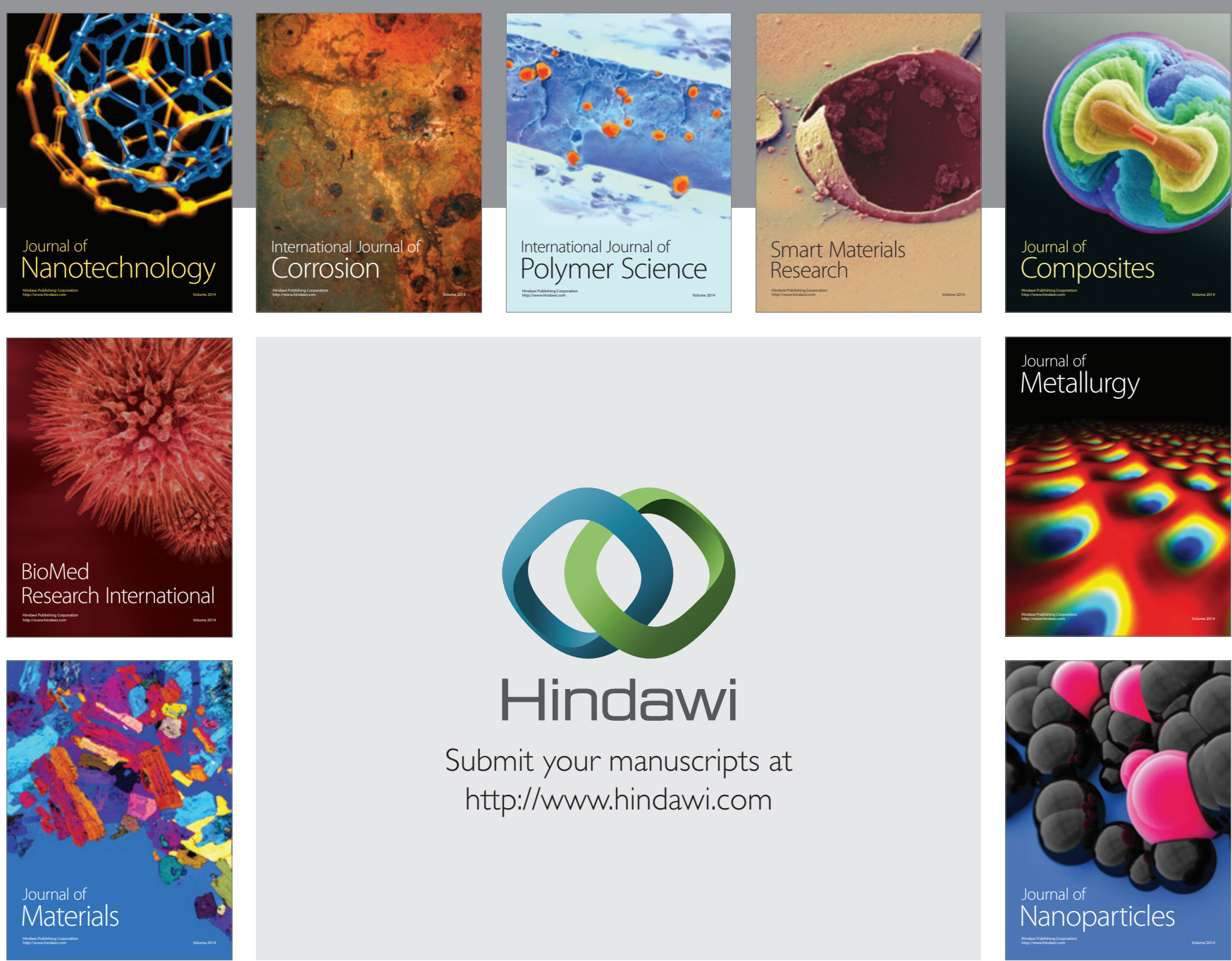

\section{Hindawi}

Submit your manuscripts at

http://www.hindawi.com

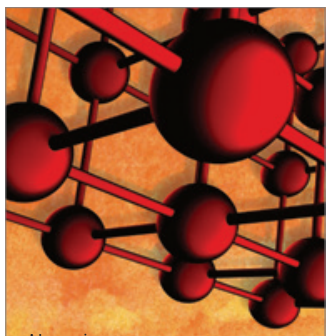

Materials Science and Engineering
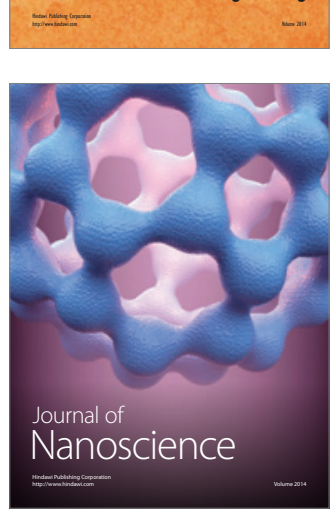
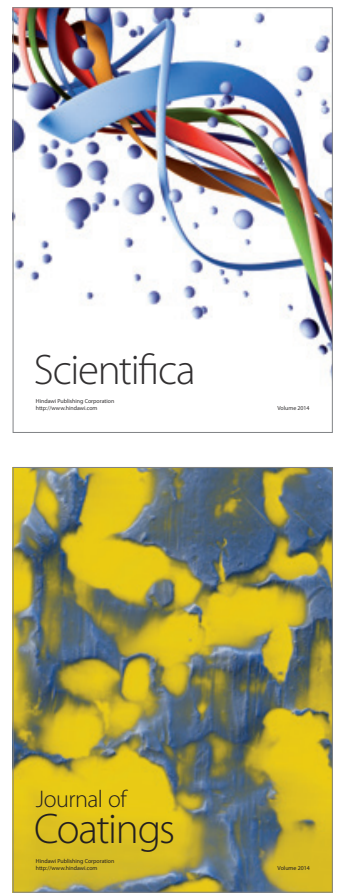
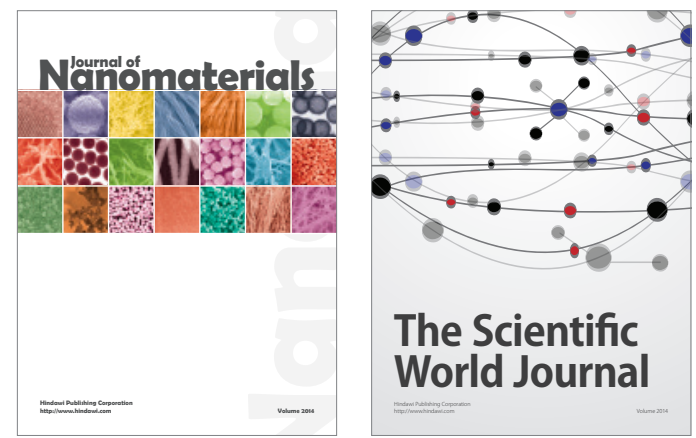

The Scientific World Journal
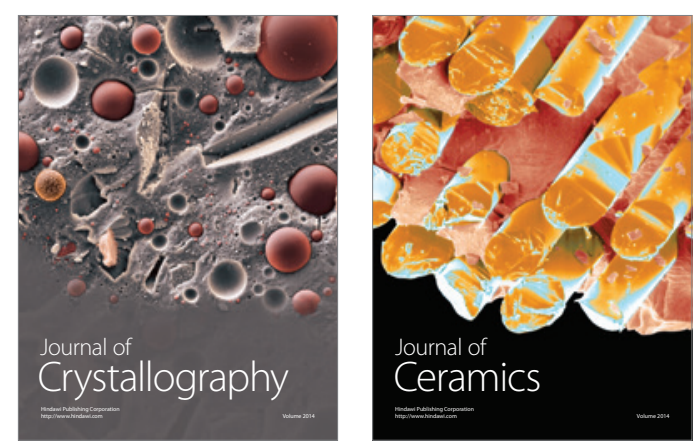
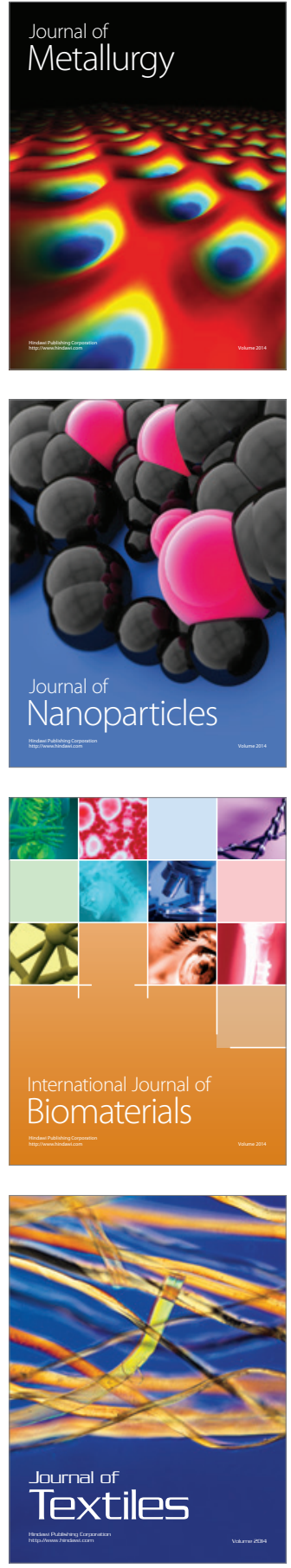